\title{
Production of Palm Oil with Methane Avoidance at Palm Oil Mill: A Case Study of Cradle-to-Gate Life Cycle Assessment
}

\author{
${ }^{1}$ Chiew Wei Puah, ${ }^{1}$ Yuen May Choo and ${ }^{2}$ Soon Hock Ong \\ ${ }^{1}$ Malaysian Palm Oil Board, Engineering and Processing Research Division, \\ 6 Persiaran Institusi, Bandar Baru Bangi, 43000 Kajang, Selangor, Malaysia \\ ${ }^{2}$ University of Malaya, Lembah Pantai, 50603 Kuala Lumpur, Malaysia
}

Received 2013-08-08, Revised 2013-08-31; Accepted 2013-09-09

\begin{abstract}
The study discusses a case study of cradle to gate life cycle assessment for the production of Crude Palm Oil (CPO) with methane avoidance at palm oil mill. The improved milling process enables total utilization of the oil palm fruit to produce alow oil palm based food source. The minimal modification in the mill includes cleaning of Fresh Fruit Bunches (FFB) and obtaining the low oil food source from the aqueous stream. The oil palm fruit processing plant enables the significant reduction of Greenhouse Gas (GHG) such as methane and carbon dioxide emissions by avoiding the formation of liquid biomass in the form of Palm Oil Mill Effluent (POME). The attributional Life Cycle Assessment (LCA) shows the improved milling process contributes to significant reduction of GHG emission from palm oil mills as compared to the process of capturing biogas from POME. The palm based food source contains phytonutrients, namely carotenoids, tocols (tocopherol and tocotrienols) and water soluble polyphenols.
\end{abstract}

Keywords: Carbon Footprint, Greenhouse Gas, Oil Palm Biomass, Palm Oil Mill Effluent

\section{INTRODUCTION}

The Malaysian oil palm industry is a key pillar in the national economy and this sector is pivotal in addressing rural poverty and employment generation. However, the oil palm industry has been scrutinized from the perspective of environment especially with regards to carbon footprint. The conventional palm oil mills produce Crude Palm Oil (CPO), palm kernels and solid biomass including Empty Fruit Bunches (EFB), fibers and shells. EFB is used as mulch in the plantations to preserve soil nutrients while fibers and shells are used as boiler fuel to produce steam for electricity generation at the mills. A large amount of liquid biomass in the form of Palm Oil Mill Effluent (POME) is also generated.

Ma et al. (1999) reported that for every metric ton of palm oil produced, about 3.35 metric ton of POME is generated. For year 2012, based on the palm oil production of close to 19 million metric ton in Malaysia, an estimate of 64 million metric ton of POME was generated. POME contains very high amount of organic matter as indicated by its high Biochemical Oxygen Demand (BOD) and is highly polluting (Ma, 1999). Therefore, various treatment and disposal methods have been developed to treat POME to prevent the negative environmental impact. Most palm oil mills in Malaysia adopt the ponding system for anaerobic digestion which produces $28 \mathrm{~m}^{3}$ of biogas for $1 \mathrm{~m}^{3}$ of POME treated. The biogas consists of 60 to $70 \%$ methane, 30 to $40 \%$ carbon dioxide and trace amount of hydrogen sulfide (Ma et al., 1999). Nevertheless, POME is considered as non-toxic as no chemicals were added during the extraction process (Khalid and Mustafa, 1992).

The Government of Malaysia imposes the regulatory standards for POME as stipulated in the Environmental 6 Persiaran Institusi, Bandar Baru Bangi, 43000 Kajang, Selangor, Malaysia 
Quality (Prescribed Premises) (Crude Palm Oil) Regulations 1977, under the Environmental Quality Act 1974. POME discharged from the mills must meet among others, the BOD requirement of less than 100 ppm. Complicated treatment system is required to reduce the $\mathrm{BOD}$ to the acceptable level for discharge into watercourses. Selected states in Malaysia are regulating a more stringent level of BOD discharge from POME of less than $20 \mathrm{ppm}$. However, most palm oil mills were not able to meet the regulatory requirements due to the limitations of technological advancement in treatment of POME.

Based on the life cycle assessment study conducted by Vijaya et al. (2010), it was recommended that the mills to capture biogas for conversion into renewable energy in order to significantly reduce the climate change impact category from palm oil mills operation. However, it was discussed that this initiative is not actively adopted by the industry due to among others, high cost of investment and the lack of infrastructures associated with national grid connection. Thus, there is an urgent need to prevent the generation of POME instead of allowing its generation and subjecting to subsequent treatment.

Therefore, it is desirable to develop an improved oil palm fruit processing plant which enables total utilization of oil palm fruit to produce value added products containing lipid soluble phytonutrients and water soluble phenolic compounds with significant reduction of GHG.

\section{MATERIALS AND METHODS}

\subsection{Oil Palm Fruit Processing Plant}

This case study was conducted based on a typical palm oil mill with an improved palm oil milling process for the extraction of CPO from FFB harvested from a typical oil palm plantation. Puah et al. (2008) had developed the improved process which included washing of palm fruits with water. The cleaned fruits were subjected to conventional palm oil milling process. The low oil food source was obtained from the aqueous stream of the process.

\subsection{Life Cycle Assessment}

The Life Cycle Assessment (LCA) study was conducted according to the ISO 14040 and ISO 14044. This case study involves the cradle to gate system boundary. The life cycle inventory of this study considered the production of seedlings at nursery (Halimah et al., 2010) and production of FFB at oil palm plantations on mineral soil (Zulkifli et al., 2010). The inventory for gate to gate for the production of CPO was obtained from this study. Mass allocation of by-products considered in this study included palm kernel and palm shells at palm oil mills (Vijaya et al., 2010). The functional unit used for this study was the production of one metric ton CPO using improved milling process with methane avoidance. The life cycle impact assessment was conducted using SimaPro version 7.1 software and Eco-Indicator 99 methodology.

\section{RESULTS}

Figure 1 showed the weighted life cycle impact assessment of cradle to gate for production of CPO with methane avoidance at palm oil mill. Figure $\mathbf{2}$ showed the normalization results for the production of one metric ton CPO through methane avoidance from this study as compared to harvesting of $85 \%$ biogas from POME at palm oil mills from Vijaya et al. (2010).

\section{DISCUSSION}

Figure 1 showed the weighted life cycle impact assessment of cradle to gate for production of CPO with methane avoidance at palm oil mill. The weighted results showed that the impact categories with significant contributions included fossil fuels, respiratory inorganics and climate change. However, these are contributed mainly by production of FFB at the oil palm plantations. The fossil fuels impact category was attributed by the fertilizers and diesel for in-field transportation. The other impact categories were also predominantly contributed by activities in the upstream related to air emissions including emission from the production of fertilizers.

Figure 2 showed the normalization results for the production of one metric ton $\mathrm{CPO}$ through methane avoidance from this study as compared to harvesting of $85 \%$ biogas from POME at palm oil mills from Vijaya et al. (2010). Although harvesting of biogas from POME has been identified as one of the most important measures to reduce GHG from palm oil mills, methane avoidance had been shown to contribute to greater GHG emission reduction. The results of this case study showed that oil palm fruit processing plant can be a potential alternative to mitigate climate change and global warming. As shown in Figure 2, the climate change impact category was significantly reduced. In addition, the improved milling process also contributes to compliance with even the more stringent regulatory requirements of $<20 \mathrm{ppm}$ Biochemical Oxygen Demand (BOD) of discharge for POME as there is virtually no discharge. Although water is used for washing of palm fruit, the use of process water at palm oil mills does not have significant impact on the impact categories. As such, the modification does not contribute to environmental impact. 
Chiew Wei Puah et al. / American Journal of Applied Sciences 10 (11): 1351-1355, 2013

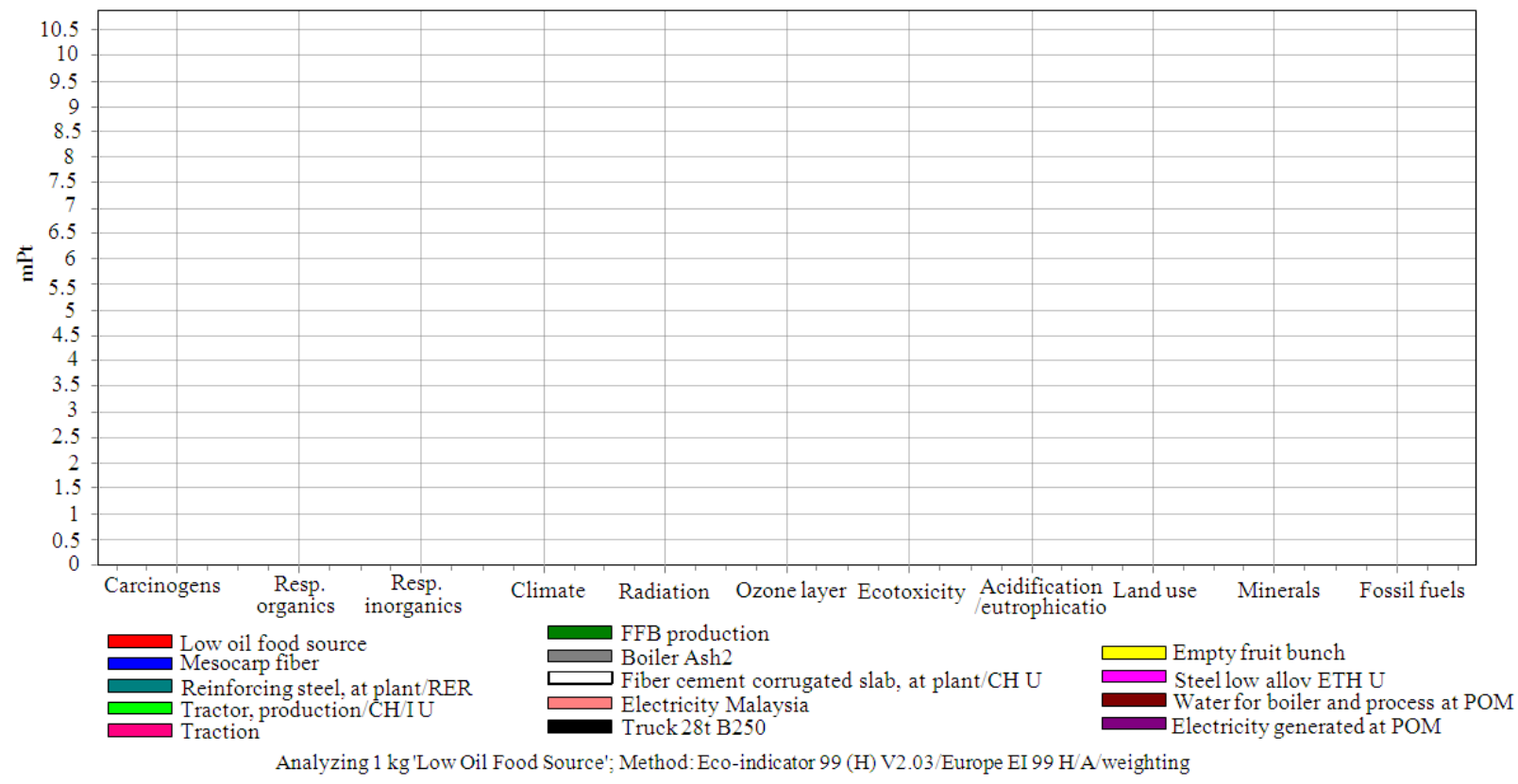

Fig. 1. Weighted life cycle impact assessment of cradle to gate for production of crude palm oil with methane avoidance at palm oil mills

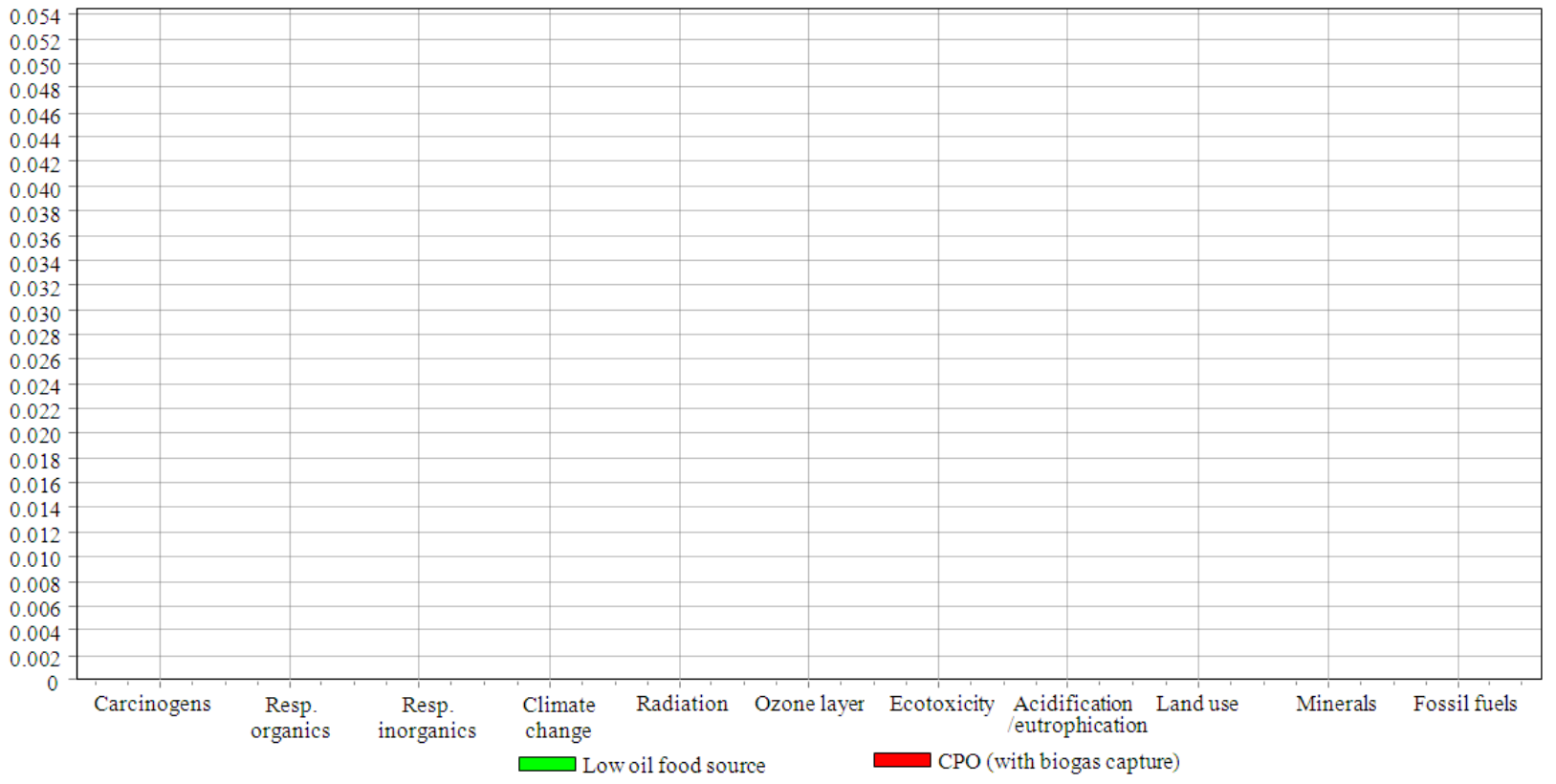

Comparing 1 ton 'Low Oil Food Source' with 1 ton 'CPO (with biogas capture)'; Method: Eco-indicator 99 (H) V2.03/Europe EI 99 H/A/normalization

Fig. 2. Normalization of production of one ton crude palm oil with methane avoidance and $85 \%$ biogas capture at palm oil mills

The improved milling process produces a low oil food source in addition to CPO and palm kernels at the mills. Research studies indicated that consuming a low energy food helps to lower calorie intake and therefore helps to manage weight. The low oil food source contains 500-700 $\mathrm{kcal} / 100 \mathrm{~g}$ with water content of $60-80 \%$. Thus, it is an 
alternative food source with lower calorie intake. The heavy metal content in the low oil food sourceis well below the permissible limit in food source. The low energy food source contains $<0.01 \mathrm{mg} \mathrm{kg}^{-1}$ of mercury and $<0.1 \mathrm{mg} \mathrm{kg}^{-1}$ of lead, cadmium and arsenic.

The food source contains both the lipid and water soluble phytonutrients. The lipid soluble phytonutrients include carotenoids and tocols (tocopherol and tocotrienols). Total carotenoids content was determined using MPOBTM (2005) and the total carotenoids content was expressed as ppm of $\beta$-carotene. The individual tocols composition was determined by method described earlier (Puah et al., 2007) and the quantification was carried out using a five-point external standard calibration assay, with $R^{2}$ value $>0.99$. The low oil food source contains 500-700 ppm of carotenoids and 600$1,000 \mathrm{ppm}$ of tocols which were similar to that of CPO (Goh et al., 1985). Carotenoids are important as the precursors of vitamin A and act as antioxidants by quenching singlet oxygen and scavenging free radicals. Tocols are also potent antioxidants that neutralize excess free radicals, exhibit vitamin E activity and cholesterollowering properties.

The low oil food source also contains water soluble phytonutrients such as phenolics. Total phenolics content was determined by the Folin-Ciocalteu method as described by Gao et al. (2000). Gallic acid was used as standard reference material and the total phenolics contents were expressed as Gallic Acid Equivalents (GAE). Phenolics are potent biological and chemical antioxidants for applications in foods and edible oils. The low oil food source contains 30,000 ppm phenolics in terms of GAE (dry weight) and 1,300 to $2,500 \mathrm{ppm}$ in terms of GAE (wet weight).

\section{CONCLUSION}

The results of this study showed that the improved milling process enabled the total utilization of palm fruit and reduced the GHG emission from the production of CPO. The approach of methane avoidance by preventing the formation of liquid biomass in the form of POME had been found to contribute to significant reduction of climate change impact category using the LCA study. Total utilization of oil palm fruits also increases the value of oil palm by producing a low oil palm based product which is suitable as a low energy food source, containing both water and lipid soluble phytonutrients. With the increasing global focus and trend towards production of sustainable products, it is pertinent to note that the Malaysian oil palm industry continues to adopt measures towards reducing GHG emission, subsequently reducing impact to the environment. In the longer term, these will contribute towards strengthening the exports of palm oil and palm oil products as well as contribute towards economic and social development of the country. In addition, the low oil food source is a nutritional palm-based food product that could further contribute the generation of income to the oil palm industry.

\section{ACKNOWLEDGEMENT}

The researchers wish to thank the Director General of MPOB for permission to publish this study.

\section{REFERENCES}

Gao, X., M. Ohlander, N. Jeppsson, L. Bjork and V. Trajkovski, 2000. Changes in Antioxidant Effects and Their Relationship to Phytonutrients in Fruits of Sea Buckthorn (Hippophae rhamnoides L.) during Maturation. J. Agric. Food Chem., 48: 1485-1490. DOI: $10.1021 / \mathrm{jf9} 91072 \mathrm{~g}$

Goh, S.H., Y.M. Choo and S.H. Ong, 1985. Minor constituents of palm oil. J. Am. Oil Chem. Soc., 62: 237-240. DOI: 10.1007/BF02541384

Halimah, M., H. Zulkifli, S. Vijaya, Y.A. Tan and C.W. Puah et al., 2010. Life cycle assessment of oil palm seedling production (Part 1). J. Oil Palm Res., 22: 878-886.

Khalid, R. and W.M.W. Mustafa, 1992. External benefits of environmental regulation: Resource recovery and the utilization of effluents. Environmentalists, 12: 277-285. DOI: 10.1007/BF01267698

Ma, A.N., 1999. Environmental management for the palm oil industry. Palm Oil Dev., 50: 1-10.

Ma, A.N., T.S. Toh and N.S. Chua, 1999. Renewable Energy from Oil Palm Industry. In: Oil Palm and the Environment: A Malaysian Perspective, Gurmit, S., K.H. Lim, L. Teo and D.K. Lee (Eds.), Malaysian Oil Palm Grower's Council, Kuala Lumpur, ISBN-10: 9838080985, pp: 253-259.

MPOBTM, 2005. Determination of carotene content. Method Malaysian Palm Oil Board., 26: 194-197.

Puah, C.W., Y.M. Choo and S.H. Ong, 2008. Oil palm fruit processing plant. Malaysian Patent Application PI 20083758.

Puah, C.W., Y.M. Choo, A.N. Ma and C.H. Chuah, 2007. The effect of physical refining on palm Vitamin E (Tocopherol, Tocotrienol and Tocomonoenol). Am. J. Applied Sci., 4: 374-377. DOI: 10.3844/ajassp.2007.374.377 
Chiew Wei Puah et al. / American Journal of Applied Sciences 10 (11): 1351-1355, 2013

Vijaya, S., Y.M. Choo, M. Halimah, H. Zulkifli and Y.A. Tan et al. 2010. Life cycle assessment of the production of crude palm oil (Part 3). J. Oil Palm Res., 22: 895-903.
Zulkifli, H., M. Halimah, KW. Chan, YM. Choo and W. MohdBasri, 2010. Life cycle assessment for oil palm fresh fruit bunch production from continued land use for oil palm planted on mineral soil (Part 2). J. Oil Palm Res., 22: 887-894. 